\title{
DEBORDERING AND EVERYDAY (RE)BORDERING IN AND OF DOVER: POST- BORDERLAND BORDERSCAPES
}

Kathryn Cassidy ${ }^{a}$ Nira Yuval-Davis ${ }^{b}$ and Georgie Wemyss ${ }^{b}$

${ }^{a}$ Department of Geography, Northumbria University, Newcastle-upon-Tyne, UK;1

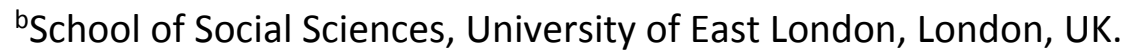

Abstract

In this paper, we argue that traditional borderlands have undergone a rapid transformation in recent decades, as a result of multiscalar de- and rebordering processes. We draw on recent insights from critical border studies to re-examine one of its historical sites of research, Dover in South East England. In doing so, we seek to elucidate what happens in border towns, when de- and re-bordering processes effectively displace key aspects of the border elsewhere. We argue that this shift is critical not only due to the decline of economic opportunities and ties to the border, but also because these necessitate new narratives and understandings or imaginaries amongst borderlanders. Whilst all elements of the border have not been dispersed, many have materially 'moved' elsewhere. We posit that Dover, like other border settlements, has become a post-borderland borderscape, where we can see evidence of everyday bordering processes similar to those elsewhere in the UK and use a situated, intersectional framework to illustrate the impact that differential social positionings have upon experiences of and perspectives on de-and-reborderings.

Keywords: Bordering, Intersectionality, Borderwork, Immigration

\footnotetext{
${ }^{1}$ CONTACT: Dr. Kathryn Cassidy, Department of Geography, Northumbria University, Newcastle-upon-Tyne, NE1 8ST, kathryn.cassidy@northumbria.ac.uk,
} 


\section{INTRODUCTION}

In this article we ask critical questions about what happens to so-called borderlands when the border or more accurately 'borderings' are displaced to other spaces. In doing so, we explore recent processes that have been the key focus of critical border studies, which have challenged theoretically the territorial fixity of borders (van Houtum and van Naerssen, 2002; Newman, 2011; Scott, 2011), but also emergent policies which undermine processes that gave some credence to at least a public sense of fixity (Author B et al in press, b). We posit that being in and of the borderland has long constituted a sense of belonging for UK borderlanders and that although the 'place' of the border has now been challenged conceptually, for many borderlanders, despite its precarity, it gave both material and symbolic meaning to life in the borderlands. In acknowledging the dynamic of socially and spatially differentiated processes of bordering, much recent work has shifted the focus away from the 'traditional' empirical sites of border studies - border communities. Here, we draw these insights together to better understand exactly how these borderscapes (Brambilla et al, 2016) are being deconstructed and reconstructed through the differentially situated gazes of borderlanders.

We argue for a post-borderland borderscape - a space which remains embedded in its narratives of the border(land) in spite of a complex array of de- and rebordering processes, which have shifted social, economic and political relations. But just like any 'post', what came before is an imaginary, a construction of fixity or territory which still lingers on in the situated imaginations (Stoetzler and Yuval-Davis, 2002) of the borderlanders, who derived meaning and understanding from it. We argue that in such a borderscape, (post-)borderlanders undertake a range of practices or 
'borderwork' in everyday life in order to challenge these emergent processes, which do not reflect their understanding of the borderland. In disputing these processes, borderlanders' differentially situated gazes are visible, as their accounts of what was past and present are contradictory and, at times, conflictual. To fully understand postborderland borderscapes, we need to operate a dialogical epistemology (Hill-Collins, 1990) encompassing these varied situated gazes which contribute different aspects as well as perspectives of the local situation.

State-sponsored de-bordering processes in border towns, such as Dover, have contributed to a reduction in employment in occupations traditionally associated with the 'industry' of the border, e.g. at the port. With the construction of the Channel Tunnel, whose entrance for vehicles is based in nearby Folkestone and whose frequent trains services now connect London directly with cities on the continent, such as Paris and Brussels, the border has to a great extent materially moved elsewhere; to the Eurostar terminals in St Pancras and Gare du Nord for those travelling by train or to Coquelles for the Eurotunnel, due to the UK-French agreement on juxtaposed controls. These local processes have been accompanied by an increasing internalisation of (de)bordering processes, particularly as a result of recent UK immigration legislation, which have shifted borders away from the margins and into everyday life (Lahav and Guiraudon, 2000). For example, those living in the UK are now subject to immigration checks as part of everyday activities, such as in renting a home, applying for a job or bank account and accessing healthcare. At the same time whilst the port has remained one of the busiest in Europe, the town of Dover has become increasingly disconnected from activities there. This is evident in the stream of traffic that still uses the port for cheaper travel to the continent and the coaches 
that whisk cruise passengers away from the Western Docks to the quaint historic streets of Canterbury or the retail outlets at Ashford.

In framing Dover as a 'post-borderland' borderscape, we draw a connection between the emergence of borders or borderings in other spaces and the debordering (Sohn, 2014) of border areas and explore the differentially situated perspectives of local inhabitants as they seek to understand these changes. In our analysis, we draw upon Anzaldua's 'mestiza consciousness' (2007) of the borderlands, which challenges the essentializing approaches common to early identity and minority political struggles. We argue that whilst the border may have become less present due to debordering processes, it remains a central theme in local consciousness(es) or border imaginaries, which are bound up in but not reducible to national-level contextual discourses in the media and politics. Our situated intersectional approach presents an alternative to methodological nationalism by utilizing a holistic, place-based analytical lens, which encompasses migrants and non-migrants. Caglar (2016) believes this is necessary as a means to create coevalness between migrants and non-migrants and deconstruct the boundaries inherent in the vast majority of literature on migration. Caglar suggests the use of 'emplacement', i.e. the processes by which all urban dwellers attempt to create a place for themselves in cities amidst 'the processes of dispossession and displacement [...] entangled with the accumulation of capital and the restructuring processes of cities' (Caglar 2016: 10). An intersectional approach situates migrants and non-migrants within processes of social stratification, dehomogenizes them and does not privilege (non)'migrantness' ahead of other categorisations. In this case we are concerned less with processes impacting cities and more with restructuring of the UK's borderlands, and in Dover in particular because of the ongoing importance of the 
border in local imaginaries, even in light of the displacement of some bordering processes to other locations.

This paper is drawn from ethnographic research we carried out in Dover (and surrounding areas), primarily between April 2013 and May 2014. The material used in the paper was, therefore, collected before the 'Brexit' EU referendum had taken place, but the nostalgic hankering for 'proper' national borders evident in the imaginaries of the people we interviewed is one of the factors which contributed to the fact that Dover, like the overwhelming majority of English and Welsh coastal towns, voted to leave the EU. The notion of the post-borderland borderscape which is presented in this article is a descriptive snap shot of a particular time-place construction which no doubt will change again dramatically as a result of Brexit. However, this does not diminish its analytical importance as one of the outcomes of de- and re-bordering processes that have taken place as a result of the EU political project as well as wider political, economic and technological globalisation processes. We begin the paper with a brief description of processes of debordering in and of Dover, focusing particularly on infrastructural changes including the construction of the Channel Tunnel, the 'Sangatte Protocol' and juxtaposed controls, EU labour migration and the 'border-as-resource' (Sohn, 2014). We then present a short review of the relevant literature on bordering(s), borderlands and borderwork, framing the need for a situated intersectional approach to border studies. Following a brief methodological note, we use in the final section of the paper ethnographic material from Dover to explore differentiated perceptions and experiences of the bordering, de-and-rebordering processes. 


\section{DEBORDERING DOVER}

\section{$\underline{\text { Infrastructural Change and Debordering }}$}

Whilst the 'debordering' in and of Dover can be linked more widely to historical changes in travel and tourism, we will commence our detailed review of these processes with the opening of the Channel Tunnel. The tunnel itself had been part of contemporary academic and policy debates since the 1950s, which led initially to a proposal in 1963 upon which the current tunnel is based. After a false start in 1973, the plan was relaunched in 1981 at the Anglo-French summit. The tunnel was seen to be a means to remove what was widely considered to be a final barrier to the single market of the European Economic Area, namely direct road and rail links to the continent (Fayman et al, 1995). The so-called bottleneck caused by ferry transportation at Dover was to be bypassed by a rail connection from nearby Folkestone to Coquelles in France. Unlike in France, where plans for the tunnel involved collaboration between central, regional and local government, planning on the British side was very much undertaken by central government (Dundon-Smith \& Gibb, 1994).

At the same time as the Channel Tunnel was completed, Dover also became connected to the new M20 motorway via a dual carriageway extension to the A20, which opened in 1993. This extension links the port directly to the motorway and at the same time cuts the town off from the port. Dover remains the UK's busiest port, carrying 12.7 million short sea international ferry passengers (a 7\% annual increase), however this figure was $20 \%$ lower than in 10 years previously (Department for Transport, 2013). International sea passenger journeys for all ports have been in decline since the Channel Tunnel opened in 1994 (ibid). 


\section{Debordering and Juxtaposed Controls}

The tunnel opened in 1994 and in addition to the loss of traffic through Dover, which will be discussed in more detail below, the construction of the tunnel also led to the signing of an agreement between France and the UK, the so-called 'Sangatte Protocol' (1991). According to the protocol, French and British immigration and customs officials would undertake checks on the territory of the other state, i.e. for the French in Folkestone and the British in Coquelles. These have become known as the juxtaposed controls and were extended in 2000 to encompass train services from France and in 2004 to incorporate Belgian services as well. Consequently, not only were immigration and customs checks, an important element of the borderwork undertaken in border areas, moved from Dover, but in 2003 the juxtaposed controls for immigration were also applied to ferry crossings, shifting these controls from Dover to Calais and Dunkirk. Calais has increasingly become a more prominent site for the UK border since these developments, with the UK Border Force, French border police and customs opening a joint operational co-ordination centre in Calais in 2010. As UK immigration officials travel to Calais and beyond, they no longer use the ferries from Dover, but travel via the Channel Tunnel.

\section{$\underline{\text { Rebordering and EU Labour Migration }}$}

Freedom of movement within the EU has been central to diversifying the population of Dover over the last decade or so. Amongst EU nationals who have chosen to come and live in the town were Czech and Slovak Roma, who were refused asylum in the 
1990s and then returned to the town to join the small Roma community following enlargement (in 2004 and 2007) to settle for work. This shift has been central to framing bordering imaginaries in the town. Between 2012 and 2013 (when our fieldwork began), the population in the Dover district is estimated to have grown by 600 people (0.5\%). Migration was the largest component of this population change (500 people) in the district. The rapacious advance of displaced Londoners seeking homes in affordable spots within commuting distance of the capital has also yet to reach Dover; the town is missing from articles on 'up-and-coming property hot spots', which have included many of its neighbours, such as Folkestone and Deal. Migration from the EU Accession States in particular has begun to shift the population of Dover, which remains less diverse than the rest of Kent and the UK as a whole. The number and proportion of migrants has increased steadily over the years. Just under half of Kent's migrant population of 133,752 people arrived before the year 2001 whilst just over half, $50.3 \%$, arrived in the past decade.

\section{'Border-as-Resource' in Dover}

All of these de- and rebordering processes have been unfolding at a time of economic decline in the town of Dover itself. In $2015,11.5 \%$ of the $16-64$ age population of the district ${ }^{2}$ were claiming out of work benefits, compared to $9.2 \%$ in Kent, $7.4 \%$ in the South East and a national average of 10.3\% (Dover District Council, 2015). Median Gross Weekly earnings were $3 \%$ below the national average and $6 \%$ below the average for the South East. The overall employment rate in the district is low at $64.8 \%$

\footnotetext{
${ }^{2}$ Dover district is comprised of the town, as well as the neighbouring towns of Deal and Sandwich and rural areas along the coast and inland.
} 
compared to $75.8 \%$ in the South East and $72.5 \%$ nationally. However, in Dover town and particular wards there are even higher levels of deprivation. St. Radigund's ward of Dover is also in the top $5 \%$ most deprived areas with $39.8 \%$ of the population being defined as income deprived. Similar patterns were found in exploring employment and education, training and skills deprivation. Whilst we do not claim a causal link between the changes in 'the border industry' and Dover's higher than average levels of deprivation, it is evident in the data we gathered in the town that these processes have become entwined in the imaginaries of the differentially situated actors.

\section{BORDERINGS AND BORDERWORK IN BORDERLAND BORDERSCAPES}

The introduction to this special issue and many other scholars (cf. Brambilla, 2015), have described the shift in critical border studies since the 1980s as the 'processual turn'. Border research moved beyond static views of border spaces and contested classical notions, which had embedded themselves in everyday understanding, that political borders were somehow 'natural' or 'just there' (Green, 2009: 2). Borders came to be seen as porous and no longer as fixed or given entities (Alvarez, 1995). This represented a challenge to the territorialising logic of the nation-state, recognising cultural processes in which such discourses had also become embedded and naturalised (Winichakul, 1996). Critical border studies have engaged in deconstructing the claims inherent in nation-state building processes. As Knippenberg (2002) has argued, territories of nation-states are not home to a homogenous population, but claims to unity forcibly assimilate diverse population whilst at the same time excluding or marginalising others (van Houtum and van Naersson, 2002). 'Bordering' is better 
understood in terms of complex processes of differentiation within space (ibid) to create particular dynamic, shifting and contested borderscapes (Brambilla, 2015). Processes of territoriality involve the borderwork (Rumford, 2008) of the construction and maintenance of boundaries. Through this process, power in popular representations can be constructed as residing in the territory itself and not with those who control it. Once created, a territory becomes the primary way in which we are socialised through practice and discourse (Paasi, 2003). This control is both material, i.e. of the land itself but also symbolic, i.e. of identity and belonging. We offer an analytical framework, which broadly explores three aspects of borderings - where, how and who - which we argue, are central to understanding the differential gazes of borderlanders in Dover.

\section{The 'Where': Borderings as Situated in Space and Time}

In this first section, we consider the ways in which scholars have theorised borderings as being situated in both space and time; in simple terms, the 'where' of borderings. Analysis of borders has focused on deconstructing some of their assumed characteristics; constructs which had become embedded in popular imaginaries. For example, Sarah Green (2009) has argued for a need to challenge the linearity of borders. By deconstructing linearity, border scholars have been able to engage in critiques of borders as stable, permanent, unchanging and definite. State boundaries have been reconceptualised as outcomes of modern state formation (Paasi, 2002; Paasi, 2005). They are a process of territoriality whose function is to delimit and contain the state but also co-exist with contemporary transnational and globalized 
flows and scales of connection that cross but do not simply dissolve national boundaries (cf. Paasi, 1999; Newman, 2006; Newman and Paasi, 1998).

Critical border studies shifted its empirical focus from geopolitical borders themselves to incorporate internal territories of nation-states. This shift is based upon an understanding that bordering is linked to wider processes of social ordering (van Houtum at al, 2005). Therefore, in spite of the vast resources designated by nationstates to border control, it is now generally accepted that borders do not seal off one entity from another (Reid et al 2013), but they also do not create a territory devoid of contestation from within. There are complexities of difference, hybridity and commonality that co-exist across borders and there are sites of ongoing negotiation of nation and ethnicity on either side.

Recent literature has acknowledged a proliferation in the forms and practices shaping these bordering processes, which has 'brought them in from the margins' both in real and discursive terms (Lahav and Guiraudon, 2000). Cons and Sanyal (2013) have argued that we see these internal and external bordering processes as both relational and comparative. These ongoing academic developments have taken place at the same time as politics and policy agendas in border control have undergone processes of de- and re-territorialization. Border policy and regimes have entered into everyday life across Europe and beyond. Residents of these countries are increasingly subject to 'bordering' practices in their day to day life (Balibar, 2002) that produce exclusion and differential inclusion (Mezzadra and Neilson, 2012), into multi-layered political boundaries. Borderings have, therefore, come to be seen not only as spatially diffused and differentiated but also inscribed upon and carried in the bodies of those who move among us (Balibar, 2002; Coleman and Stuesse, 2014; Joseph and Rothfuss, 
2014). Whilst borderings might be theorised to take place anywhere at anytime, they are still shaped by both wider political projects of belonging (Yuval-Davis, 2011) which define the boundaries of the national collectivities, as well as narratives of popular imaginaries and situated gazes of differential social positionings. Bordering scholars now undertake research across a range of different sites and locations. For us, these multiple scales can be explored in the context of everyday life (Yuval-Davis et al. in press a).

The dynamic, temporal nature of borders has been central to the processual turn and is embedded in the term bordering. In this paper we also explore the trans-temporal multiplicity of borderings. Drawing on work by feminist theorists of time (eg Radstone, 2007; Grosz, 1999), Green (2009) argues for a sense of border, which recognises multiplicity and historical contingency, so borderings, as such, are taking place in the present but are being shaped by the past and the future. Like a trace, according to Derrida, borderings can be seen to invoke something that never existed, i.e has been imagined, in order to make sense of the present (Derrida 1997: 65-67). These transtemporal constructions are particularly important when we try to understand the imaginaries of post-borderlanders. Massey's work on space can give us further insights regarding the situatedness of borderings. Where it is particularly useful to our approach to situated, everyday bordering is in exploring the multiplicity and in incorporating a sense of dynamism and change. Whilst Derrida sees spaces as 'dead time' (1997: 68) or in which time is stopped, Massey argues that space is entirely lively, constituting a 'simultaneity of stories so far' (Massey 2005: 12). Thus, space is the outcome of multiple relations, unpredictable happenings and everyday activities. This is because, Massey argues, the mere fact of being positioned means a difference from 
being positioned elsewhere. In other words, the 'trace,' for Massey, is an absolute, irreducible difference intrinsic to being located. Therefore, a central theme emerging in critical border studies has been an understanding of borders as not just spatially but also temporally (dis)located. This has led to calls for new approaches to studying borders, which enable scholars to 'capture' these temporal elements. For example, Nick Megoran (2012), has suggested we research and write the biographies of borders to understand their dynamism. We would argue, however, that such biographies should reflect the situated gazes of the different social agents involved in the borderwork maintaining and constructing these borders.

\section{The 'How': Borderwork and Borderworking}

Border scholars have increasingly acknowledged that bordering processes are made through practices, whether these are aimed at maintaining and strengthening them or at disrupting or subverting them (Reid et al, 2013:5). These practices operationalize 'symbols, signs, identifications, representations, performances and stories' (van Houtum et al, 2005). Such practices incorporate a variety of different actors and Painter (2006) has argued that at the edge of the state this is primarily through institutions, whose role is then to differentiate between people and objects in order to determine their mobilities (Henry, 2008). These ordinary practices take place in everyday life and are overlapping, relational and often contradictory as they are enacted by individuals with differentiated social positionings. For Painter (2006), such practices are embedded in bordering processes as the mundane making of territory, but as studies of everyday bordering have shown (Johnson and Jones, 2016; YuvalDavis et al, in press, b), bordering practices involve many more dimensions than the 
mere territorial. In contrast to early border studies, we take a critical approach to understanding not only who moves and who does not but also who is in a position of control in relation to movement and how such controlling practices are carried out. Rumford (2008) has theorised borders as being like a computer firewall, i.e. they perform intelligent filtering of immigrants, being open for the attractive and closed for the unwanted. However, we would argue that Rumford's approach privileges the national and that there is a need for a further analytical lens through which scholars can challenge the dominance of what has been termed methodological nationalism, i.e. the ways in which scholarship presupposes the nation-state to be the primary unit of analysis (Beck, 2002; Wimmer and Glick Schiller, 2003; Amelina and Faist, 2012). Part of this methodological shift needs to include regional control of borderings (e.g. Frontex, Vaughan-Williams, 2008) as well as global. However, the methodological lens has to be redirected inwardly, not just outward, and focus on different kinds of social agents.

The shifts in the border studies' literature we have discussed, reflect broader changes within approaches to theorising geopolitics, including the emergence of an interest in micro-politics (Philo and Smith, 2003), everyday life (cf. Pain and Smith, 2008) and ethnographic approaches (Megoran, 2006). It is important to acknowledge that our approach in to the study of bordering is embedded in the field of feminist geopolitics, which challenges the dominance of elite and macro-level geopolitical theorisation, in part by focusing on people and the everyday. Like critical (or anti) geopolitics, feminist approaches both critique classical geopolitical accounts as well as develop alternative theorisations grounded in the practice and place of groups marginalised by traditional geopolitics (Koopman, 2011). As such, feminist geopolitics is a transformative 
intellectual space, suggesting new directions and avenues for change (Hyndman, 2004). There have recently been really important interventions drawing on the field of feminist geopolitics, which have explored everyday bordering practices in the context of differentially situated groups, such as asylum seekers (Gill, 2009), refugees (McConnell, 2013) and post-trafficked women (Laurie et al, 2015). Intersectional analysis of everyday bordering - another legacy of feminist theory, however, should not just replace the study of how those in control carry out the borderwork with focusing on how those who are marginalized contest them. Rather, we argue that in order to understand the ways borderings work, we need to include as many social agents involved in borderworking, from the centre and the margins, as possible, as the only way to approach a comprehensive and valid understanding of borderwork. This is probably even more important in post-borderland borderscapes than in others, due to the central roles of transtemporal and translocal imaginaries in the everyday bordering processes that take place there.

\section{The 'Who': Everyday Borderworkers}

As well as shifts in the theorisation of borderings as being differentially situated in space and time and the practices involved in borderwork, critical border theorists have also suggested that non-state actors have increasingly become involved in doing this 'borderwork' (Doty, 2007; Rumford, 2006; Rumford, 2008) 'from below' (Doevenspeck, 2011); they have been encouraged to play the role of the 'citizendetective' (Vaughan-Williams, 2008), reporting any suspicions to the authorities. As part of changes to immigration legislation in the UK over the last two decades and its amplification since the June 2016 referendum on leaving the European Union, a 
coercive regime of fines and penalties has introduced bordering practices in the UK into the roles of employers, landlords, healthcare workers and teachers/lecturers as well as other workers in the public and private domains. In our work we have pointed out that the development of this everyday bordering technology of control have made virtually everyone into (usually unpaid, untrained) border guards as well as often suspected illegitimate border crossers (Yuval-Davis et al, in press, b).

Therefore, borders are generated by people who are informed in their practices by notions of what constitutes border as well as by new and emerging formal bordering regimes. As Butler (2009: 44) has argued boundaries are a negotiation of difference, in which individuals become bound together in the processes of establishing their difference. As a performative process, bordering(s) invoke not only official but also personal memories and understandings of places (Green, 2010). As borders have not left the scene of human territoriality and have in fact become more extensive in society and everyday performance, there is a need for further development in our analytical frameworks in this field. For us, this is about more than exploring the complexity of bordering practices (van Houtum et al, 2005: 2). Our contribution in this special issue is not only to acknowledge these multiple vantage points or sides to borders but to recognise that through the use of intersectionality as a theoretical and methodological approach we can draw close to the multiplex epistemological framing of situated gazes which direct the practices of bordering. Brambilla et al (2016) suggested borderscaping as a new analytical tool for contemporary bordering studies, and indeed, as will emerge later in the paper, post-borderlands can be seen as a particular type of borderscape. However, for us, what is most important is not the scape as such but rather the various situated, often conflicting, processes of everyday 
bordering. We recognise that this is not an apolitical endeavour, as research on borders and bordering is in itself part of bordering processes. Theories of what constitutes 'border-ness' - the meaning, purpose and qualities of border - inform the building of borders and their associated imaginaries. Also the activities and practices that generate how borders engage with, and help to create, the world in their own image (Krasteva, 2015; Buerkner, 2015).

Borderings are practices that are situated and constituted in the specificity of political negotiations as well as the everyday life performance of them. They shift and are contested between individuals and groupings as well as in the constructions of individual subjectivities. The impact of this for borderlanders has been to disrupt the connection (real and imagined) between living at the border and borderwork.

METHODOLOGICAL NOTE: SITUATED, INTERSECTIONAL, EVERYDAY BORDERINGS IN DOVER

We approached bordering processes in Dover from a situated intersectional perspective (Yuval-Davis, 2011; 2014). The basic claim of this theoretical/methodological approach is that in order to understand a social process or a social encounter, there is a need for a dialogical epistemology (Hill-Collins, 1990) of the different participants who view - and are affected by - the situation in different ways, depending on their differential social positionings, identifications and normative value systems.

Epistemologically, intersectionality can be described as a development of feminist standpoint theory, which claims, in somewhat different ways, that it is vital to account for the social positioning of the social agent. However, intersectionality theory was 
interested even more in how the differential situatedness of different social agents relates to the ways they affect and are affected by different social, economic and political projects. An important facet of our situated intersectionality approach, therefore, is to differentiate between social positionings, identifications and normative values which are all related but not reducible to each other.

Methodologically, different intersectionality approaches have tended to use what Lesley McCall (2005) calls inter- or intra-categorical approaches. By inter-categorical approach McCall means focusing on the way the intersection of different social categories, such as race, gender and class affect particular social behaviour or distribution of resources. Intra-categorical studies, on the other hand, are less occupied with the relationships among various social categories but rather problematize the meanings and boundaries of the categories themselves, such as whether black women were included in the category 'women' or what are the shifting boundaries of who is considered to be 'black' in particular place and time. Our approach combines the macro socio-economic perspective of the inter-categorical approach with the sensitivity and dynamism of the vernacular intra-categorical approach.

Since our overall methodological approach focused on grounding the theoretical insights through investigating everyday bordering imaginaries and social practices of differently situated officials, permanent and temporary residents/border-crossers, we employed ethnographic research methods to capture those complexities. We carried out multiple observations, five focus groups and 34 interviews in Dover, Folkestone and Ashford. The majority of these took place between April 2013 and May 2014. The interviews and focus groups were with women and men from a range of backgrounds 
and ages, including people who cross/have crossed the border with and without papers, who live nearby but do not cross the border, labour migrants, people whose everyday employment is directly or indirectly related to the border, those who are 'local' and those who have had experience of crossing multiple borders inside and outside Europe. They were supplemented by 15 informal conversations and attendance at 13 meetings by state and voluntary organisations involved in borderwork in Kent. We were unable to gain official access to make observations of and question people who work 'at the border', however, through attending Home Office sponsored Migration Strategy meetings, contacts were made that resulted in interviews with two Border Force officials and conversations with two more during participant observation of an engagement event $\mathrm{i}$ as well as visiting an immigration removal centre.

\section{SITUATED INTERSECTIONAL PERSPECTIVES ON BORDERINGS IN AND OF THE (POST-)}

\section{BORDERLANDS}

\section{Debordering Processes in and of Dover}

In this first section, we explore the ways in which the debordering processes have shifted spatial imaginaries of Dover amongst many local residents and how they have contested the changes. What is apparent in the narratives that ensue is that the border itself served not only as a resource providing formal and informal borderwork but also as a point of connection for the town. Consequently, de-bordering processes have led to an increasingly disconnected and 'left behind' feeling. AD, a professional woman in her late 30s, had grown up and lived much of her life in Dover. She 
emphasised how the place of Dover, at the UK's margins but geographically proximate to Calais, led to a pride emerging from its connections to France.

I think it's something that Dover is quite proud of, [...] you hear it a lot; people saying its only 21 miles to France. London gosh! That's 70 miles away. You could say people feel more not affiliated, but more connected to France than London. I know more people who have gone to France more than London, when I was young. It's different now, high speed rail links and so on, but as a child, it was often the case that you had some sort of relative who was working on the ferries so you would always go.

Here we see examples of the negotiation of difference (Butler, 2009) undertaken by borderlanders. Whilst explaining how traditional borderwork, in this case employment on the ferries, has been diminished and replaced by the high speed rail links that have disconnected Dover from the border, $A D$ also elucidates how debordering disrupted local spatial imaginaries or ordering/othering (van Houtum and van Naersson, 2002), in which the border was centrally placed.

As well, as connecting the town to Calais and France, the border also shaped its positionality and distinctive links to other parts of the UK. In this case, borderwork became a key element (re)shaping the spatialities of intimate and familial life in the town.

And then [...] we had a big influx of people from the North, Liverpudlians and so on, Mancunians who would come down for bootlegging[....]and a lot of people settled down here actually. Yeah there is quite a lot of people I know now [...] who have husbands and such from Liverpool and Manchester who they met in their early twenties who had come down here to do the bootlegging and 
did two or three years of cigarette runs. [....] and it would all get ferried back up North, but you would have whole teams of people who would be living in the bed and breakfasts down here. (AD, Dover)

However, differential social positionings led to contested narratives of this period of 'smuggling'. The friends AD spoke of were working class and lower middle class women from the town. Their acceptance of the men who came from the North West was challenged by an older, middle class woman we spoke to during a visit to the town in 2013. She was critical of the high numbers of drug addicts, who she believed were not local people but had come from Liverpool and other places and were linked to informal borderwork of cross-border trading. These everyday negotiations surrounding the border, highlight not only the transtemporality of the border or bordering (Yuval-Davis, 2014), as the past is being remade in the present and the reach of debordering beyond the port, into Dover and its connection to other place, but also emphasise that understandings of these processes are contested in everyday life and both re-produce and extend socio-cultural boundaries.

Some narratives of debordering processes focused on the loss of both formal and informal borderworking opportunities at the port, which led to a growing sense of distance between the town and the port itself. These shifts in economic and spatial relations were narrated differently by the middle classes. Here we saw a focus on the lifestyle and leisure implications of fewer local people crossing the border to France, as a local tourism professional (JD) explained.

In the days when I started to live in Dover - nearly 25 years ago now - you could cross the channel for a pound, two pounds, nowadays it is considerably more expensive to travel, and that does affect the way that you do things. We used 
to go for our team Christmas lunch in Boulogne. We can't do that anymore, it is too expensive.

In this way we see again how the border becomes distantiated from the town reducing the sense of ownership and connection to the border, which had long been a feature of everyday life. However, unlike in AD's case where border-crossing was dependent on a relative working at the port or linked to 'smuggling', local professionals and the middle classes found prices rises to have disrupted the 'border as leisure'. This was again evident in a comment made by PD, a health visitor who worked but did not live in the town, 'I didn't know Dover well. I only live 15 miles away, but I probably would have mainly come here just to go across the channel.'

JD's situated gaze was further revealed in his description of the impact that the improved road links between the port and the motorway were having on the town. His description explains the marked shift in spatial relations, which further moved the border away from the town, but from a particular perspective.

So more and more people are crossing from France in vehicles than were in the past. So they are not walking from the port up the high street, buying whatever they want from Marks and Sparks and then going home. They are coming across in a car so they are much move able to move around East Kent and further afield. So it isn't about Dover-Calais anymore.

Again we see his very specific gaze, which captures only some of the users of the port - mostly tourists and holidaymakers. This group were also the concern of another local professional, TD, who was the manager of a prominent retail space in the town and had become concerned about the growing disconnection between the port and the town. TD felt that local attempts to address the material barrier the new road had 
created between the town and port through the construction of an underpass also failed. She described the underpass as 'uninviting and intimidating' to pedestrians. In these examples, it is clear that debordering is felt across the local community and not just amongst those directly involved in working at the port, but in the ways the changes are narrated, the situated gaze (Stoetzler and Yuval-Davis, 2002) of the individual reveals their particular social positioning. These everyday negotiations surrounding the border, highlight not only the transtemporality of the border or bordering, as the past is being remade in the present and the reach of debordering beyond the port, into Dover and its connection to other places, but also emphasise that understandings of these processes are contested in everyday life.

It also became apparent that the debordering processes described by various residents and workers in Dover were also producing new localised border(ing)s. These can be seen as a series of (re)bordering imaginaries that discursively produced Dover as the 'other'. One 16-year-old boy from Folkestone referred to his home town as 'not as bad as Dover'. Other local towns were often constructed as more desirable places by a cross-section of the community. SN was a wife of a serving soldier in a Gurkha regiment, whom we met in Dover.

Now we stay in Dover, but in June we are going to Canterbury as we have already buy a house for us. [...]Because it is city centre, there is lots of scope and opportunity for job as well, part-time or full-time and there are lots of schools around Canterbury centre.

A local policewoman suggested that only the most marginalized of migrants stayed in and around Dover, as those who were able to, moved further away. These discourses suggest that in a very real way, whilst borders have been moving away from the 
margins and into everyday life, as Lahav and Guiraudon (2000) have suggested, they have taken with them the processes that connected border towns, such as Dover to other places (from the local port to other parts of the UK, as well as France and the continent), thus leading to a growing sense of disconnection and marginalisation in the town.

\section{Everyday Bordering and Belonging in the (Post-)Borderland Borderscapes}

In this section, we explore the intersection of everyday bordering, particularly in discursive practices, and belonging. In this way, we show how new conflicts have arisen in post-borderland Dovorian society linked to the town's increasing diversity. Whilst many emphasized the importance of the borderwork generated by the port, some local residents saw Dover's role as one of transience, not settlement. One middle-aged Dovorian woman described the town as 'a doorway', through which people from other parts of the world move on and spread out. However, for those coming from outside Dover, there was an expectation of diversity as something which would be synonymous with the borderland. As PD explains, 'Well, when I came here, I thought Dover would be bristling with asylum seekers but there is only about 50 or so, I think that is the figure.' For the middle classes, it was also clear that to some extent increasing diversity was constructed as a sign of 'success', perhaps increasing the similarity with more cosmopolitan urban centres. AD, who was from a working class background, described how this had caused conflict with her friends from school. So for me personally [....] I think that is probably one of the best things that ever happened to Dover because it dragged Dover from being out of touch with the rest of the world, it dragged Dover into the $21^{\text {st }}$ century where the 
reality is multicultural, multiracial and multi-ethnic and a town like Dover, being a passenger port, if it cannot deal with multi-ethnicity, multiculturalism, different people, then how will it ever be successful as a port?

She and some of the other public sector workers we spoke to in the town saw diversity as some sort of symbol of progress and something to be welcomed. PD, the health visitor, stated, 'I've been over to [local school] myself sometimes for meetings and there's a whole array of different coloured children from different nationalities and I think it is great, multiculturalism.'

These views were not shared by all in the town and surrounding areas. In a conversation with some young people at a local youth project, it became clear that more nuanced discourses of belonging were emerging.

NK: No 'cause well with immigration....there are quite a lot of people that have come over here but in Dover, where it's a port area, there are more.

JS: Eastern Europeans, mostly Eastern Europeans.

Interviewer: So for example here you have quite a lot of people from Nepal?

DN: They're more Cheriton and Hawkinge-based.

JS: And they're really nice.

NK: And they serve our country. Whereas Czechs and Slovakians just....

JS: You sound racist mate.

NK: Quite a few of them just....

DN: Come over here and bum around and stuff.

JS: They're just not very nice people.

NK: Just scrounge off the government.

JS: Yeah. 
NK: Our tax money's going to them.

JS: Not all.

NK: A percentage of it.

Here we see young people engaging in internal practices of borderwork and a form of b/ordering migrants within the area. At the same time, there are links to wider political and media discourses surrounding the 'utility' or the 'benefits' migrants may or may not bring to the UK. As has been argued elsewhere (Craig, 2011), Britain has long sought through its immigration policies to minimise supposed economic impacts of migration. In a sense, it seems that the border is not able to perform the intelligent filtering of migrants (Rumford, 2008), and these informal discourses in everyday life become the spaces in which such filtering now takes place. But as we see in the young people's conversation, such discourses are not without contestation in everyday life. As PD demonstrated above, the imaginary of a border town or a borderland is often one of mixing and multi-ethnicity (Anzaldua, 2007). However, the young people's comments illustrate how the openness of the border to EU labour migrants was contested from a number of situated perspectives and represented the emergence of very clear discourse of non-belonging in the town. It was these and similar (re)bordering discourses which were so evident leading up to the UK's EU referendum. A local business owner, AS, who had converted to Islam, also noted earlier hostility to any increasing diversity.

When the Roma came there was clearly a very negative reaction, which was quite abusive. I mean I remember we used to have lots and lots of quite violent attacks on asylum seekers involving metal bars, people getting run over, reversed over, knife attacks, things like this. It was a strong reaction but I think 
after a couple of years people had already become used to seeing people of quite a different colour, different language.

Whilst the violence may have abated, the emergent discourses that classified migrants did not always reflect their own experiences. Even though they were more widely accepted locally, some Nepali women we interviewed discussed the difficulties they experienced due to their citizenship, which were often hidden from the view of the majority population, who seemingly welcomed them.

Yes, most of the time, my children ask in the holiday time, July, in the six week off school, they ask, mum, let's go somewhere for holiday, my friends went, and I want to go but the main reason is my passport[...]. It is like a pressure on me [....] It feels bad but what can we do?

The border between the UK and France was in many ways closed to Nepali soldiers and their families, who were constructed positively in local discourses of belonging. We also observed (re)borderings of Roma and other EU migrants (See also Wemyss and Cassidy, 2017), as the health worker, PD explained.

The interpreter I work with, she was quite upset one day, she is Czech, but she would call herself 'white Czech'. [...] the local paper had a large picture on the front page of a Roma guy who had been drunk one night and had smashed in a door. It is an average Saturday night crime if you like, but it was on the front page of the paper, after the court case, and she said, that is basically just stirring up negative feelings about them, and I have to agree.

Discourses differentiating Roma from other 'problematic' families of all backgrounds were evident across service providers, who saw their 'needs' as being distinct (cf. Wemyss and Cassidy, 2017). In everyday borderworking the heterogenous nature of 
the local Roma population was being obscured in wider bordering discourses. This often led to counter-narratives amongst those working more closely with these communities - demonstrating the negotiation of the border in everyday life by those in differential social positionings.

You know I also see a difference in between Czech Romas and Slovakian Romas. [..] well Czech had always been a richer country than Slovakia and we were always poorer part in Czechoslovakia. Slovakia was always the poor part. So the Czech Romas are, [...] and I don't want to be judgmental...but if you stood two children from Czech Republic and Slovakia, you'd know which one is from which country. Not by the skin but by hygiene, cleanliness, by the way they spoke, by the way they are dressed. [...] But yeah Czechs are a bit more integrated I would say also than Slovakians.

This worker discusses the boundaries as embodied in the children (carried on their bodies after Balibar, 2002) of these families - visible to the outsider through the cleanliness.

In this section of the paper, we have explored a different form of what we term borderwork and it's practices, which echoes much more clearly those practices observed in many communities - the discursive production of difference - often framed by media and political discourse (Wemyss and Cassidy, 2017). For us, such practices must be incorporated into any analysis of borderwork both internal and external to nation-states, as there is clearly a link between discourses of belonging and those who are refused entry to and the right to reside legally on a territory, as exemplified by the UK's referendum on EU membership. Accounts suggest an improvement in the way in which the population of Dover responded to the new 
arrivals, but our research has shown that new discourses of belonging have, in fact, been emerging, in which some migrants are viewed as deserving, whilst others are depicted as problematic. Within the discursive production of belonging, the situated gazes and social positionings of local workers and inhabitants are revealed through their differentiated narratives. By positioning accounts from migrants alongside the majority population, we can see elements of the dialogical processes through which particular subjectivities, and therefore borderings, are constructed, deconstructed and reconstructed.

\section{CONCLUSION: DOVER AS A POST-PORDERLAND BORDERSCAPE}

In this paper we have introduced the concept of a post-borderland borderscape to explore what happens in border towns, when de- and rebordering processes effectively displace major elements of 'the border' elsewhere. This is critical not only due to the decline of economic opportunities and ties to the border, but also because these necessitate the emergence of new narratives and understandings or imaginaries amongst borderlanders. Whilst all elements of the border have not been dispersed, many have materially 'moved' elsewhere. Dover is a good example of such a borderscape as an old territorial border, which has been predominantly stripped of its traditional roles, with some of its functions being de- and re-terriorialized. In such borderlands, the border itself has often been constructed as a 'natural' resource and it is through the borderwork surrounding this resource that borderlanders are often connected not only to the global economy, but also the rest of their own nation-state. Therefore, as with a post-industrial space/city, when the border becomes less and less the rationale for the space, borderlanders contest these processes by continuing to 
emphasise these links to the border. We have argued for an analytical lens, which incorporates three aspects of the processual turn in border studies - where, how and who- to understand de- and reborderings in the town. We have shown that not only are borderings differentially situated away from the border and in everyday life, but also the wide range of bordering actors and practices away from the traditional work associated with the border. We have emphasised clearly the need to take a situated, intersectional approach to analysing these borderings. We have illustrated how particular narratives are shaped by social positioning and that these offer differential and, at times, conflictual accounts of the impacts of debordering in Dover.

Debordering in the EU has largely been upon the basis of creating a shared economic space, with the underlying logic that borders present barriers to trade (van Houtum and van Naersson, 2002). In fact, it is precisely the 'debordering' of a major part of Europe that has fed notions of the EU as a 'force for good in the world' (Barbe \& Johansson-Nogues, 2008). However, our research in Dover has shown that EU labour migration, in particular, has become a focus not only of contestation in the town but also of (re)bordering processes as borderlanders have undertaken their own 'intelligent filtering' of immigrants, which the border regime is constructed as no longer being able to do. Just as the impacts of debordering are socially differentiated, so these everyday rebordering processes can also be seen to be linked to the social positioning of the borderlanders. At times, these narratives reveal a desire to contest wider discourses, such as in the case of the interpreter working with the health visitor. However, it was also clear that border(ing)s, which were keenly felt by some, remained invisible to others in everyday life, such as the inability of the Nepali women to travel during school holidays. 
Borders, therefore, continue to be major planks in the constructions of postborderlands political projects of belonging. Borders as they used to be, borders as they could become, and borders which define the post-borderlanders everyday social, economic and political reality. Crucially, however, we have shown, the situated gazes of the different residents and workers in Dover. The differential social positionings, emotional identifications and attachments, as well as normative and political values of these people, differentially construct their bordering imaginaries as well as the wider related constructions of boundaries of belonging - of them, and of the different 'others' in town and country. In order to fully understand the social and political meaning of the post-borderland borderscape in Dover, we need to bring into an encompassing epistemological dialogue the different situated gazes of people who, from their own perspectives, construct different boundaries, more or less permeable between 'us' and different kinds of 'them'. 


\section{LIST OF REFERENCES}

Alvarez Jr, R. R. (1995) 'The Mexican-US border: the making of an anthropology of borderlands' Annual Review of Anthropology, 447-470.

Amelina, A., \& Faist, T. (2012) 'De-naturalizing the national in research methodologies: Key concepts of transnational studies in migration' Ethnic and Racial Studies 35(10): 1707-1724.

Anzaldúa, G. (2007). Borderlands: la frontera (4 $4^{\text {th }}$ edition) San Francisco: Aunt Lute. Balibar, E. (2002) Politics and the Other Scene. London: Verso.

Barbe, E. and E. Johansson-Nogues (2008) 'The EU as a modest 'force for good': the European Neighbourhood Policy' International affairs 84(1): 81-96.

Beck, U. (2002) 'The cosmopolitan society and its enemies' Theory, culture \& society 19(1-2): 17-44.

Brambilla, C. (2015) 'Exploring the critical potential of the borderscapes concept' Geopolitics 20(1): 14-34.

Brambilla, C., J. Laine, J.W. Scott and G. Bocchi (2015) 'Introduction: Thinking, Mapping, Acting and Living Borders under Contemporary Globalisation' in Brambilla, C., J. Laine, J.W. Scott and G. Bocchi (eds) Borderscaping: Imaginations and Practices of Border Making Routledge: London, pp.1-12.

Buerkner, H-J. (2015) 'Beyond Constructivism: Europeanisation and Bordering under the Impact of Power and Imaginaries in C. Brambilla, J. Laine, J.W. Scott and and G. Bocchi (eds.) 'Borderscaping: Imaginations and Practices of Border Making' Farnham and Burlington: Ashgate, pp. 27-40.

Butler, J. (2009) Frames of war: When is life grievable? Verso Books: New York. Çağlar, A. (2016) 'Still 'migrants' after all those years: foundational mobilities, 
temporal frames and emplacement of migrants' Journal of Ethnic and Migration Studies, 42(6): 952-969.

Coleman, M., \& Stuesse, A. (2014) 'Policing borders, policing bodies: The territorial and biopolitical roots of US immigration control' in C. Johnson, R. Jones and C. WastlWalter (eds.) Placing the Border in Everyday Life. Farnham and Burlington: Ashgate, pp. 33-63.

Cons, J., \& Sanyal, R. (2013). Geographies at the margins: borders in South Asia-an introduction. Political Geography, 35, 5-13.

Craig, G. (2011) 'Forward to the Past: Can the UK Black and Minority Ethnic Third Sector Survive?' Voluntary Sector Review 2(3): 367-389.

Department for Transport (2013) Sea Passenger Statistics London: Department for Transport.

Derrida, J. (1997) Of Grammatology (trans.) G.C. Spivak. Baltimore: Johns Hopkins University Press.

Doevenspeck, M. (2011). Constructing the border from below: Narratives from the Congolese-Rwandan state boundary. Political Geography, 30(3), 129-142.

Doty, R. L. (2007) 'States of Exception on the Mexico-US Border: Security, "Decisions," and Civilian Border Patrols' International political sociology 1(2): 113137.

Dover District Council (2015) English Indices of Deprivation Briefing Paper Dover: Dover District Council.

Dundon-Smith, D. M., \& Gibb, R. A. (1994) 'The Channel Tunnel and regional economic development' Journal of Transport Geography 2(3): 178-189. 
Fayman, S., Metge, P., Spiekermann, K., Wegener, M., Flowerdew, T., \& Williams, I. (1995) 'The regional impact of the Channel Tunnel: qualitative and quantitative analysis' European Planning Studies 3(3): 333-356.

Gill, N. (2009) 'Governmental mobility: The power effects of the movement of detained asylum seekers around Britain's detention estate' Political Geography 28(3): 186-196.

Green, S. (2009) 'Lines, traces and tidemarks: reflections on forms of borderliness' EastBordNet, COST Action ISO803 Working Paper.

Green, S. (2010) 'Performing border in the Aegean: On relocating political, economic and social relations' Journal of Cultural Economy 3(2): 261-278.

Grosz, E. (1999) Becomings: Explorations in Time, Memory and Futures Cornell University Press: Ithaca, NY.

Henry, M. (2008) ‘Border geostrategies: Imagining and administering New Zealand's post-World War One borders' New Zealand Geographer 64(3): 194-204.

Hill-Collins, P. (1990) Black Feminist Thought New York: Routledge. Hyndman, J. (2004) 'Mind the gap: bridging feminist and political geography through geopolitics' Political Geography 23(3): 307-322.

Jones, R., \& Johnson, C. (2014) Placing the border in everyday life Routledge: London. Joseph, Y., \& Rothfuss, R. (2014) 'Symbolic Bordering and the Securitization of Identity Markers in Nigeria's Ethno-Religiously Segregated City of Jos' In: Jones, R. and Johnson, C. (Eds.), Placing the Border in Everyday Life Farnham and Burlington: Ashgate, pp. 167-184.

Knippenberg, H. (2002) 'Assimilating Jews in Dutch nation-building: the missing 'pillar' Tijdschrift voor economische en sociale geografie 93(2): 191-207. 
Koopman, S. (2011) 'Alter-geopolitics: Other securities are happening' Geoforum 42(3): 274-284.

Krasteva, A. (2015) 'Spaces, Lines, Borders: Imaginaries and Images' in C. Brambilla, J. Laine, J.W. Scott and and G. Bocchi (eds.) 'Borderscaping: Imaginations and Practices of Border Making' Farnham and Burlington: Ashgate, pp. 13-26.

Lahav, G. and V. Guiraudon (2000) ‘Comparative Perspectives on Border Control: Away from the Border and Outside the State' in Andreas, P. and T. Snyder (eds.) The Wall around the West: State Borders and immigration Controls in North America and Europe Lanham, MD: Rowman and Littlefield.

Laurie, N., Richardson, D., Poudel, M., \& Townsend, J. (2015) 'Post-trafficking bordering practices: Perverse co-production, marking and stretching borders' Political Geography 48: 83-92.

Massey, D. (1994) Space, place and gender Cambridge: Polity Press

Massey, D.B. (2005) For space. London: Sage

McCall, L. (2005) 'The Complexity of Intersectionality' Signs 30(3): 1771-1800.

McConnell, F. (2013) Citizens and refugees: constructing and negotiating Tibetan identities in exile. Annals of the Association of American Geographers 103(4): 967983.

Megoran, N. (2006). For ethnography in political geography: Experiencing and reimagining Ferghana Valley boundary closures. Political Geography,25(6), 622-640. Megoran, N. (2012). Rethinking the study of international boundaries: a biography of the Kyrgyzstan-Uzbekistan boundary. Annals of the Association of American Geographers 102(2): 464-481. 
Mezzadra, S. and Neilson, B (2012) 'Between inclusion and exclusion: On the Topology of Global Space and Borders'. Theory, Culture and Society 29: 58. Newman, D. (2011) 'Contemporary Research Agendas in Border Studies: An Overview', in Doris Wastl-Water (ed.) Ashgate Research Companion to Border Studies Ashgate: London, pp.33-47.

Newman, D. (2006) 'Borders and bordering towards an interdisciplinary dialogue' European Journal of Social Theory 9(2): 171-186.

Newman, D., \& Paasi, A. (1998) 'Fences and neighbours in the postmodern world: boundary narratives in political geography' Progress in human geography 22(2): 186207.

Paasi, A. (1999) 'Boundaries as social practice and discourse: The Finnish-Russian border' Regional Studies 33(7): 669-680.

Paasi, A. (2002) 'Regional transformation in the European context: Notes on regions, boundaries and identity' Space and Polity 6(2): 197-201.

Paasi, A. (2003) 'Region and place: regional identity in question' Progress in Human Geography 27(4): 475-485.

Paasi, A. (2005) 'The changing discourses on political boundaries. Mapping the backgrounds, contexts and contents' in $\mathrm{H}$. van Houtum, O. Kramsch and W. Zierhofen (eds.) Bordering Space. Aldershot: Ashgate, pp.17-31.

Pain, R. and S. Smith (2008) 'Fear: Critical Geopolitics and Everyday Life' in Pain, R. and S. Smith (eds.) Fear: Critical Geopolitics and Everyday Life Aldershot, Hampshire: Ashgate, pp.1-24.

Painter, J. (2006) 'Prosaic geographies of stateness' Political geography 25(7): 752774. 
Philo, C. and F.M. Smith (2003) ‘Guest editorial: political geographies of children and young people' Space and Polity 7(2): 99-115.

Reid, M. B., Graham, B., \& Nash, C. (2013) Partitioned Lives: The Irish Borderlands. Ashgate: London.

Rumford, C. (2006) 'Theorizing borders' European Journal of Social Theory 9(2): 155169.

Rumford, C. (2008) 'Introduction: Citizens and borderwork in Europe' Space and Polity 12(1), 1-12.

Scott, J. W. (2011) 'Borders, border studies and EU enlargement' in Doris WastlWater (ed.) Ashgate Research Companion to Border Studies Ashgate: London, pp.123-142.

Sohn, C. (2014) Modelling cross-border integration: The role of borders as a resource. Geopolitics, 19(3): 587-608.

Stoetzler, M. and N. Yuval-Davis (2002) 'Standpoint theory, situated knowledge and the situated imagination' Feminist theory 3(3): 315-333.

van Houtum, H. and T. van Naerssen (2002) 'Bordering, ordering and othering' Tijdschrift voor economische en sociale geografie 93(2): 125-136.

Van Houtum, H., O. Kramsch, and W. Zierhofen, (2005) 'Prologue: Bordering Space' in H. van Houtum, O. Kramsch and W. Zierhofen (eds.) Bordering Space. Aldershot: Ashgate, pp:1-13.

Vaughan-Williams, N. (2008) 'Borderwork beyond inside/outside? Frontex, the citizen-detective and the war on terror' Space and Polity 12(1): 63-79. Wemyss, G. \& Cassidy, K. 'People think that Romanians and Roma are the same': everyday bordering and the lifting of transitional controls' Ethnic and Racial Studies 
40(7): 1132-1150

Wimmer, A., \& Schiller, N. G. (2003) 'Methodological nationalism, the social sciences, and the study of migration: An essay in historical epistemology' International migration review 37(3): 576-610.

Winichakul, T. (1996) 'Maps and the Formation of the Geo-Body of Siam' Tønnesson/Antlöv (Hrsg.): 67-92.

Yuval-Davis, N. (2011) The Politics of Belonging: Intersectional Contestations London: Sage.

Yuval-Davis, N. (2014) 'Situated Intersectionality and Social Inequality' Raisons Politiques 58: 91-100.

Yuval-Davis, N., Wemyss, G. and Cassidy, K. (in press, a) 'Everyday Bordering, Belonging and the Re-Orientation of British Immigration Legislation' Sociology, Yuval-Davis, N., Wemyss, G. and Cassidy, K. (in press, b) Bordering Polity Press: Cambridge. 